\title{
Chelidonine induces mitotic slippage and apoptotic-like death in SGC-7901 human gastric carcinoma cells
}

\author{
ZHONGYUAN QU ${ }^{1}$, XIANG ZOU ${ }^{2}$, XIUJUAN ZHANG ${ }^{1}$, JIEJING SHENG ${ }^{1}$, \\ YUMENG WANG $^{2}$, JIAQI WANG ${ }^{2}, \mathrm{CHAO} \mathrm{WANG}^{2}$ and YUBIN JI ${ }^{2}$ \\ ${ }^{1}$ School of Pharmacy; ${ }^{2}$ Engineering Research Center of Natural Antineoplastic Drugs, \\ Harbin University of Commerce, Harbin, Heilongjiang 150076, P.R. China
}

Received March 25, 2015; Accepted November 24, 2015

DOI: $10.3892 / \mathrm{mmr} .2015 .4683$

\begin{abstract}
The aim of the present study was to investigate the effect of chelidonine on mitotic slippage and apoptotic-like death in SGC-7901 human gastric cancer cells. The MTT assay was performed to detect the antiproliferative effect of chelidonine. Following treatment with chelidonine $(10 \mu \mathrm{mol} / \mathrm{l})$, the ultrastructure changes in SGC-7901, MCF-7 and HepG2 cells were observed by transmission electron microscopy. The effects of chelidonine on $\mathrm{G}_{2} / \mathrm{M}$ phase arrest and apoptosis of SGC-7901 cells were determined by flow cytometry. Indirect immunofluorescence assay and laser scanning confocal microscopy (LSCM) were used to detect the phosphorylation level of histone $\mathrm{H} 3\left(\mathrm{Ser}^{10}\right)$ and microtubule formation was detected using LSCM following immunofluorescent labeling. Subsequent to treatment with chelidonine $(10 \mu \mathrm{mol} / \mathrm{l})$, expression levels of mitotic slippage-associated proteins, including BUB1 mitotic checkpoint serine/threonine kinase B (BubR1), cyclin-dependent kinase 1 (Cdk1) and cyclin B1, and apoptosis-associated protein, caspase-3 were examined by western blotting at 24, 48 and $72 \mathrm{~h}$. The half maximal inhibitory concentration of chelidonine was $23.13 \mu \mathrm{mol} / 1$ over $48 \mathrm{~h}$ and chelidonine induced $\mathrm{G}_{2} / \mathrm{M}$ phase arrest of cells. The phosphorylation of histone $\mathrm{H} 3$ at $\mathrm{Ser}^{10}$ was significantly increased following treatment with chelidonine for $24 \mathrm{~h}$, indicating that chelidonine arrested the SGC-7901 cells in the M phase. Chelidonine inhibited microtubule polymerization, destroyed microtubule structures and induced cell cycle arrest in the $\mathrm{M}$ phase. Giant cells were observed with multiple micronuclei of varying sizes, which indicated that following a prolonged arrest in the $\mathrm{M}$ phase, the cells underwent mitotic catastrophe. Western blotting demonstrated that the protein expression
\end{abstract}

Correspondence to: Dr Xiang Zou, Engineering Research Center of Natural Antineoplastic Drugs, Harbin University of Commerce, 138 Tongda Street, Harbin, Heilongjiang 150076, P.R. China E-mail: zou8663202@163.com

Key words: chelidonine, SGC-7901 human gastric carcinoma cells, M-phase arrest, mitotic catastrophe, mitotic slippage, apoptotic-like death levels of BubR1, cyclin B1 and Cdk1 decreased significantly between 48 and $72 \mathrm{~h}$. Low expression levels of BubR1 and inactivation of the cyclin B1-Cdk1 complex results in the cells being arrested at mitosis and leads to mitotic slippage. In addition, apoptotic morphological changes in multinucleated cells were observed, the apoptosis rates increased gradually with administration of chelidonine in a time-dependent manner and the protein levels of caspase-3 increased significantly between 24 and $72 \mathrm{~h}$. Thus, chelidonine induces mitotic slippage, and apoptotic-like death occurs in SGC-7901 cells undergoing mitotic catastrophe. Gastric cancer is a common malignancy, and ranks second in overall cancer-associated mortalities worldwide. The present study demonstrated that chelidonine induces Mphase arrest and mitotic slippage of SGC-7901 human gastric carcinoma cells via downregulating the expression of BubR1, Cdk1 and cyclin B1 proteins. With the prolongation of chelidonine treatment, the giant cells with multiple micronuclei underwent mitotic slippage and were maintained in the $\mathrm{G}_{1}$ phase and did not survive. A number of multinucleated cells underwent apoptosis via a caspase-dependent signaling pathway. The current study proposes that chelidonine induces mitotic slippage and apoptotic-like death of SGC-7901 cells.

\section{Introduction}

Gastric cancer is a common malignancy, and ranks second in overall cancer-associated mortalities worldwide (1). Chemotherapy is an important therapeutic strategy for advanced gastric cancer, with the majority of chemotherapeutic agents functioning by inducing apoptosis of tumor cells. However, with the prolongation of chemotherapeutic treatment, certain cells become resistant to apoptosis, leading to drug resistant tumor cells. Thus, novel anticancer therapeutic agents are required and, in recent years, induction of mitotic catastrophe has become a molecular target for developing cancer treatments, which are effective against tumors that are resistant to traditional chemotherapeutic agents (2).

Chelidonium majus, the greater celandine (family, Papaveraceae), is well established in traditional Chinese medicine. It was originally included in 'Herbal for Relief of Famines' (3) and is currently included in the 2015 edition of 'Chinese Pharmacopoeia' (volume 1) (4). It typically affects the lung and stomach. Furthermore, C.majus relieves spasms, 
pain, coughs and asthma and is often administered for gastric spasm pain, pain associated with cancer, coughing, wheezing and pertussis (5). The essential secondary metabolites of C. majus are isoquinoline alkaloids, such as chelidonine, chelerythrine, sanguinarine, allocryptopine, berberine and coptisine (6). Chelidonine, the tertiary hexahydro-benzophenanthridine alkaloid, is a major component of $C$. majus. It had been reported to exhibit a broad spectrum of pharmacological activities, including anticancer (7-9), analgesic (5), anti-inflammatory (10), spasmolytic (11), hepatoprotective $(12,13)$, antioxidative (against cadmium chloride-induced oxidative stress), and nephroprotective effects (14). The present study focuses primarily on the antitumor effect. Chelidonine, as the major component of the therapeutic agent, Ukrain, has been applied in the clinical treatment of lung, breast, prostate and pancreatic cancer (15-18). It has been reported that chelidonine may overcome multiple types of drug resistance and enhance cytotoxicity of chemotherapeutic agents, particularly against leukemia cells (19), indicating that it may have potential as an anticancer agent. The antitumor mechanisms of chelidonine differ among cell lines. It was reported that chelidonine reduced telomerase activity via downregulation of telomerase reverse transcriptase expression in HepG2 cells (6), induced apoptosis via p38-p53 and phosphatidylinositol-4,5-bisphosphate 3-kinase (PI3K)/AKT signaling pathways in Hela cells (7) and induced apoptosis via the mitochondrial signaling pathway in malignant melanoma cells, regardless of their p53 status (20). However, chelidonine did not affect mitochondria intactness in human CEM T-leukemia cells (21). In a previous study, chelidonine exhibited strong antiproliferative activity in SGC-7901 human gastric cancer cells, which indicated the morphological characteristics of mitotic catastrophe. Thus, it was hypothesized that chelidonine may exert its antineoplastic effect via mitotic catastrophe. The aim of the present study was to investigate the effects and underlying mechanisms of chelidonine on mitotic catastrophe and apoptotic-like death in SGC-7901 human gastric cancer cells.

\section{Materials and methods}

Chemicals, therapeutic agents and assay kits. The following reagents were used: Chelidonine (purity, $\geq 98 \%$; Shenzhen Medherb Biotechnology, Co., Ltd., Shenzhen, China); vincristine (VCR) sulfate for injection (Zhejiang Hisun Chemical Co., Ltd., Taizhou, China); RPMI-1640 medium (Gibco; Thermo Fisher Scientific, Inc., Waltham, MA, USA); pancreatin (Gibco; Thermo Fisher Scientific, Inc.); Hyclone fetal bovine serum (FBS; GE Healthcare Life Sciences, Logan, UT, USA); dimethyl sulfoxide (DMSO; Tianjin Bodi Chemical Co., Ltd., Tianjin, China); methyl thiazolyl tetrazolium (MTT; Sigma-Aldrich, St. Louis, MO, USA); propidium iodide (PI; Sigma-Aldrich); Triton X-100 (Shanghai Huashun Bioengineering, Co., Ltd, Shanghai, China); and bovine serum albumin (BSA; Sigma-Aldrich).

Equipment. The following equipment was used: Super-clean bench (DL-CJ-1N; Beijing Donglian Har Instrument Manufacture Co., Ltd., Beijing, China), a $\mathrm{CO}_{2}$ incubator (CO-150; New Brunswick Scientific; Eppendorf, Inc., Hamburg, Germany); a microplate reader (Model 680;
Bio-Rad Laboratories, Inc., Hercules, CA, USA); an inverted microscope (CKX-41; Olympus Corporation, Tokyo, Japan); flow cytometer (COULTER ${ }^{\circledR}$ EPICS $^{\circledR}$-XL, Beckman Coulter, Inc., Brea, CA, USA); a transmission electron microscope (TEM; Hitachi-7650; Hitachi, Ltd., Tokyo, Japan); Mini-PROTEAN ${ }^{\circledR} 3$ gel electrophoresis system (Bio-Rad Laboratories, Inc.); and a laser scanning confocal microscope (SP2; Leica Microsystems, Ltd., Wetzlar, Germany).

Cell lines and cell culture. SCG-7901 human gastric cancer cells, MCF-7 human breast adenocarcinoma cells and HepG2 human hepatoma cells were obtained from Obio Technology, (Shanghai) Co., Ltd. (Shanghai, China). The cells were cultured in RPMI-1640 medium containing 10\% FBS, penicillin $(100 \mathrm{U} / \mathrm{ml})$-streptomycin $(100 \mu \mathrm{g} / \mathrm{ml})$ obtained from Beyotime Institute of Biotechnology (Haimen, China). Cells were incubated in a humidified atmosphere with $5 \% \mathrm{CO}_{2}$ at $37^{\circ} \mathrm{C}$. Culture transfer was performed once every 2-3 days.

MTT assay. SGC-7901 cells were digested with $0.25 \%$ pancreatin and seeded in a 96-well plate at a density of $1 \times 10^{4}$ cells/well. Following incubation for $24 \mathrm{~h}$, the therapeutic agents, chelidonine $(100 \mu \mathrm{l})$ or VCR $(100 \mu \mathrm{l})$, were added to each well at various concentrations. The final concentrations were: $0,5,10,20,40,80$ and $160 \mu \mathrm{mol} / 1$ chelidonine; and $0,0.1,1,10$ and $100 \mu \mathrm{mol} / \mathrm{l} \mathrm{VCR}$. Following $48 \mathrm{~h}$ of incubation at $37^{\circ} \mathrm{C}$, the culture medium and therapeutic agents were discarded, and $100 \mu \mathrm{l}$ MTT $(0.5 \mathrm{mg} / \mathrm{ml})$ solution was added to each well. After $4 \mathrm{~h}$ incubation at $37^{\circ} \mathrm{C}$, the supernatant was removed and $100 \mu \mathrm{l}$ DMSO was added. The absorbance of the solution was measured at a wavelength of $570 \mathrm{~nm}$ using the microplate reader. The optical density was used to calculate the inhibition rate and half maximal inhibitory concentration $\left(\mathrm{IC}_{50}\right)$.

Observation of the ultrastructure changes of SGC-7901 cells using a TEM. Following treatment with $10 \mu \mathrm{mol} / 1$ chelidonine at different time-points, SGC-7901, MCF-7 and HepG2 cells were fixed with $2 \%$ glutaraldehyde (Dow Chemical Co., Midland, MI, USA) overnight, and post-fixed using $1 \%$ osmic acid (Ted Pella, Inc., Redding, CA, USA). The samples were dehydrated in analytically pure graded alcohol (Tianjin Dongliqu Tianda Chemical Reagent Factory, Tianjin, China), embedded in Epon 812 resin (Wako Pure Chemical Industries, Ltd., Osaka, Japan) and sectioned by an ultramicrotome (RM2126; Leica Microsystems, Ltd.). Ultra-thin sections $(70 \mathrm{~nm})$ were counterstained with uranyl acetate (Hubei Chushengwei Chemical Co., Ltd., Wuhan, China) and lead citrate (Yingkou Tanyun Chemical Research Institute Corporation, Yingkou, China) and observed using the TEM.

Detection of $G_{2} /$ Mphase arrest and apoptosis using flow cytometry (FCM). SGC-7901 cells were treated with chelidonine (10 $\mu \mathrm{mol} / \mathrm{l})$ and VCR (3 $\mu \mathrm{mol} / \mathrm{l})$ for 24,48 and $72 \mathrm{~h}$, collected and fixed with $70 \%$ ethanol (Shandong Lerkan Medical Technology Co., Ltd., Dezhou, China) at $4^{\circ} \mathrm{C}$ overnight. Cells were collected, washed three times with phosphate-buffered saline (PBS; Beyotime Institute of Biotechnology) and stained with $800 \mu \mathrm{l}$ PI for $30 \mathrm{~min}$ at room temperature in the dark. The samples were analyzed using FCM at an excitation wavelength of $488 \mathrm{~nm}$. 
Detection of histone $\mathrm{H} 3\left(\mathrm{Ser}^{10}\right)$ phosphorylation using $L S C M$. Cover slips were placed in a 6-well plate, and SGC-7901 cells were seeded in each well $\left(\sim 3 \times 10^{4}\right.$ cells/well $)$ and allowed to attach overnight. The cells were treated with $2.5,5$ or $10 \mu \mathrm{mol} / 1$ chelidonine for $24 \mathrm{~h}$, fixed with $4 \%$ paraformaldehyde for $30 \mathrm{~min}$ and were processed by $0.5 \%$ Triton $\mathrm{X}-100$ for $15 \mathrm{~min}$. Following washing three times with PBS, the cells were maintained in BSA for $1 \mathrm{~h}$ and incubated overnight with mouse anti-human $\mathrm{pH} 3\left(\mathrm{Ser}^{10}\right)$ polyclonal antibody (1:500; cat. no. AH453; Beyotime Institute of Biotechnology) at $4^{\circ} \mathrm{C}$. Subsequently, the samples were incubated with 1:200 fluorescein isothiocyanate (FITC)-conjugated goat anti-mouse immunoglobulin $\mathrm{G}$ (heavy and light chains) $[\operatorname{IgG}(\mathrm{H}+\mathrm{L})$; cat . no. A0568; Beyotime Institute of Biotechnology] for $1 \mathrm{~h}$ at $37^{\circ} \mathrm{C}$ in the dark. The samples were washed twice with PBS, mounted and observed using LSCM.

Detection of microtubule morphology following immunofluorescent labeling by LSCM. Cover slips were placed in a 6-well plate and SGC-7901 cells were seeded in each well $\left(\sim 3 \times 10^{4}\right.$ cells/well $)$ and allowed to attach overnight at $37^{\circ} \mathrm{C}$. Following treatment with $2.5,5$ or $10 \mu \mathrm{mol} / 1$ chelidonine or $3 \mu \mathrm{mol} / \mathrm{l} \mathrm{VCR}$ for $24 \mathrm{~h}$, the cover slips with cells were washed twice with PBS, fixed with $4 \%$ paraformaldehyde for $30 \mathrm{~min}$ and treated with $0.5 \%$ Triton X-100 for $15 \mathrm{~min}$. The cover slips were blocked with BSA for $1 \mathrm{~h}$, washed twice with PBS and covered on a clean glass slide. The mouse anti-human tubulin monoclonal antibodies (1:500; cat. no. AT819; Beyotime Institute of Biotechnology) were added to the samples and incubated overnight at $4^{\circ} \mathrm{C}$. The samples were incubated with FITC-conjugated goat anti-mouse $\operatorname{IgG}(\mathrm{H}+\mathrm{L})$, diluted 1:200, for $1 \mathrm{~h}$ at $37^{\circ} \mathrm{C}$ in the dark. The samples were washed twice with PBS, mounted, and observed using LSCM.

Detection of BUB1 mitotic checkpoint serinelthreonine kinase B (BubR1), cyclin-dependent kinase 1 (Cdk1), cyclin B1 and caspase-3 protein expression levels using western blotting. Following treatment with $10 \mu \mathrm{mol} / 1$ chelidonine for 0, 24, 48 and $72 \mathrm{~h}$, the SGC-7901 cells were collected and lysed with lysis buffer (Beyotime Institute of Biotechnology) in an ice bath for $1.5 \mathrm{~h}$. Subsequent to centrifuging the lysates at $13,000 \mathrm{x} \mathrm{g}$ for $15 \mathrm{~min}$ at $4^{\circ} \mathrm{C}$, the protein content of the supernatant was quantified by Coomassie Brilliant Blue assay (Beyotime Institute of Biotechnology). The cell lysates were separated by $12 \%$ SDS-PAGE (Tianjin Kemiou Chemical Reagent Co., Ltd., Tianjin, China) for $\sim 2 \mathrm{~h}$ at $80 \mathrm{~V}$ and blotted onto a nitrocellulose membrane (Beyotime Institute of Biotechnology). Membranes were incubated in a blocking buffer [5\% non-fat dry milk in a mixture of Tris-buffered saline (prepared from $2.5 \mathrm{~g} \mathrm{NaCl}$ obtained from Tianjin Dongliqu Tianda Chemical Reagent Factory and $2.5 \mathrm{ml}$ Tris- $\mathrm{HCl}$ at $1 \mathrm{~mol} / 1$ and $\mathrm{pH} 7.5$ obtained from Beyotime Institute of Biotechnology, dissolved in double-distilled water to $250 \mathrm{ml}$ ) and Tween-20 (Beyotime Institute of Biotechnology; TBST)] for $2 \mathrm{~h}$ at room temperature, and blots were incubated with polyclonal antibodies, as follows: Rabbit anti-human BubR1 polyclonal antibody (1:250; cat. no. bs-5726R; Beijing Biosynthesis Biotechnology Co., Ltd., Beijing, China), rabbit anti-human cyclin B1 polyclonal antibody (1:200; cat. no. bs-5072R; Beijing Biosynthesis Biotechnology Co.,

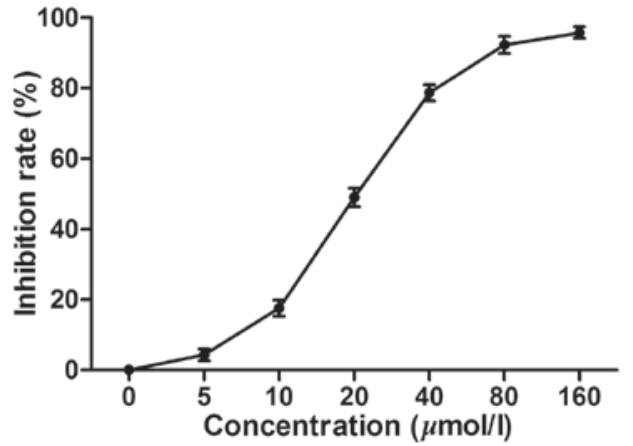

Figure 1. Inhibitory effects of chelidonine on the proliferation of SGC-7901 cells. The cells were cultured for $24 \mathrm{~h}$ and incubated with $0,5,10,20,40$, 80 and $160 \mu \mathrm{mol} / 1$ chelidonine for $48 \mathrm{~h}$. Cell viability was determined using the MTT assay. Chelidonine inhibited proliferation of SGC-7901 cells in a dose-dependent manner. The half maximal inhibitory concentration was $23.13 \mu \mathrm{mol} / 1$.

Ltd.), rabbit anti-human Cdk1 polyclonal antibody (1:200; cat. no. bs-0081R; Beijing Biosynthesis Biotechnology Co., Ltd.)or rabbit anti-human caspase-3 polyclonal antibody (1:200; cat. no. bs-0081R, Beijing Biosynthesis Biotechnology Co., Ltd, Beijing, China) at $4^{\circ} \mathrm{C}$ overnight. The membrane was rinsed with TBST and incubated with goat anti-rabbit $\operatorname{IgG}(\mathrm{H}+\mathrm{L})$ labeled with alkaline phosphatase (1:5,000; cat. no. bs-0295G; Beijing Biosynthesis Biotechnology Co., Ltd.) at room temperature for $2 \mathrm{~h}$. The membrane was rinsed three times with TBST, and incubated with 3,3'-diaminobenzidine tetrahydrochloride (DAB; Beijing Zhongshan Golden Bridge Biotechnology Co., Ltd., Beijing, China) for $\sim 10 \mathrm{~min}$ in the dark at room temperature. Finally, the membranes were observed using a gel imaging system (GIS-219; Tanon Science and Technology Co., Ltd., Shanghai, China).

Statistical analysis. The data obtained from the different groups were expressed as the mean \pm standard deviation, and statistical analysis was performed using one-way analysis of variance with SPSS for Windows, version 15.0 (SPSS, Inc., Chicago, IL, USA). P $<0.05$ was considered to indicate a statistically significant difference.

\section{Results}

Chelidonine inhibits the proliferation of SGC-7901 cell lines. The MTT assay demonstrated that chelidonine markedly inhibited the proliferation of SGC-7901 cells in a dose-dependent manner. The $\mathrm{IC}_{50}$ was $23.13 \mu \mathrm{mol} / \mathrm{l}$ (Fig. 1) while the $\mathrm{IC}_{50}$ of the positive control, VCR was $5.28 \mu \mathrm{mol} / 1$ (data not shown).

Chelidonine treatment results in multinucleated and apoptotic morphology of SGC-7901 cells. To determine the occurrence of mitotic catastrophe, a TEM was used to observe the multinucleated cells induced by chelidonine (Fig. 2). In the control group, normal morphological characteristics of tumor cells were observed, such as clear cellularity, integrated structure of the organelles, and uniform distribution of chromatin (Fig. 2A-C). Following treatment with $10 \mu \mathrm{mol} / 1$ chelidonine for $24 \mathrm{~h}$, nuclear envelopes formed around chromatin at random, resulting in the presence of multinucleated 
Table I. Effects of chelidonine on the phosphorylated-histone H3 $\left(\operatorname{Ser}^{10}\right)$ expression in SGC-7901 cells $(n=30)$ following a 24-h treatment.

\section{Group}

Fluorescence intensity

\section{Control}

$21.79 \pm 1.75$

Vincristine $(\mu \mathrm{mol} / \mathrm{l})$

$$
3
$$

$54.01 \pm 2.83^{\mathrm{a}}$

Chelidonine $(\mu \mathrm{mol} / \mathrm{l})$
2.5
$32.15 \pm 2.00^{\mathrm{b}}$
5
$45.72 \pm 1.52^{\mathrm{a}}$
10

${ }^{\mathrm{a}} \mathrm{P}<0.01$ vs. the control; ${ }^{\mathrm{b}} \mathrm{P}<0.05$ vs. the control.

cells with multiple micronuclei of various sizes (Fig. 2D-F). Following treatment with chelidonine for $48 \mathrm{~h}$, the number of multinucleated cells increased gradually. The multinuclear cells exhibited the apoptotic morphology of reduced microvilli (Fig. 2G). Following treatment with chelidonine for $72 \mathrm{~h}$, the multinuclear cells exhibited chromatin condensation, nuclear fragmentation and formation of the apoptotic body (Fig. $2 \mathrm{H}$ ).

Chelidonine induces $G_{2} / M$ phase arrest of SGC-7901 cells. Following 24, 48 and $72 \mathrm{~h}$ of exposure to $10 \mu \mathrm{mol} / 1$ chelidonine, SGC-7901 cells demonstrated significant accumulation in the $\mathrm{G}_{2} / \mathrm{M}$ phase, which was accompanied by a decrease of cells in the $G_{0} / G_{1}$ and $S$ phases. Following treatment with $10 \mu \mathrm{mol} / 1$ chelidonine for $24 \mathrm{~h}$, the $\mathrm{G}_{2} / \mathrm{M}$ phase cell ratio was $47.30 \%$, which reached 58.55 and $88.12 \%$ at 48 and $72 \mathrm{~h}$, respectively. The apoptosis rates were 9.09, 22.28 and $29.93 \%$ following treatment with chelidonine for 24,48 and $72 \mathrm{~h}$, respectively (Fig. 3). The result demonstrated that chelidonine induces $\mathrm{G}_{2} / \mathrm{M}$ phase arrest and apoptosis of SGC-7901 cells.

Chelidonine increases histone $\mathrm{H} 3\left(\mathrm{Ser}^{10}\right)$ phosphorylation in SGC-7901 cells. With the increase in chelidonine concentration, the phosphorylation of histone $\mathrm{H} 3\left(\mathrm{Ser}^{10}\right)$ was significantly increased following $24 \mathrm{~h}$ treatment (Table I). Similar to the positive control, VCR, chelidonine induced the arrest of SGC-7901 cells in the M phase.

Chelidonine inhibits microtubule polymerization in SGC-7901 cells. The control microtubules (labeled with green fluorescence) were distributed evenly in the cytoplasm surrounding the nucleus, and the single microtubules demonstrated a clear outline and complete structure. The microtubules of the SGC-7901 cells treated with $5 \mu \mathrm{mol} / 1$ chelidonine for $24 \mathrm{~h}$ were discontinuous and their number was reduced. The microtubules of SGC-7901 cells treated with $10 \mu \mathrm{mol} / 1$ chelidonine were not bundled, however, marginal fluorescence was observed with diffuse, punctate and irregular distribution in the perinuclear region. In the positive control group, the cells were round and the fluorescence intensity was weak. The microtubule-targeting agent, VCR inhibited microtubule polymerization (Fig. 4).
A

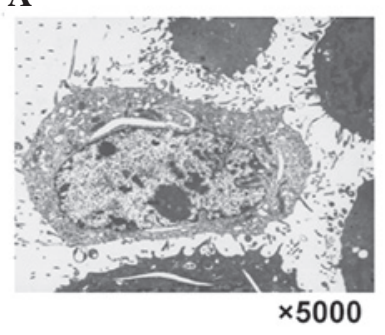

C

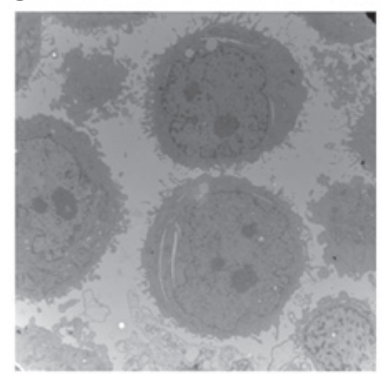

$\mathbf{E}$

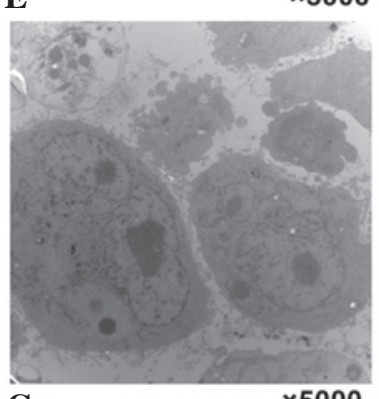

G

$\times 5000$

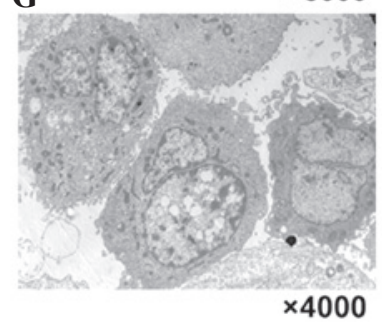

H

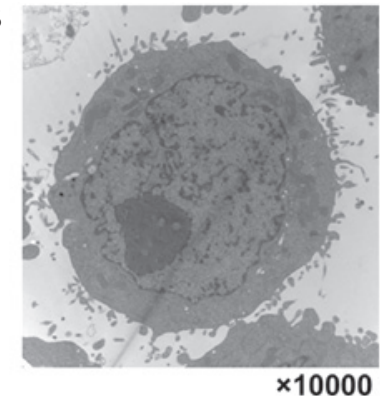

D

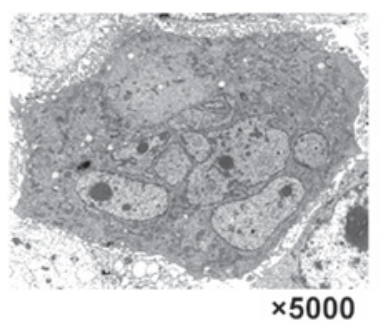

F

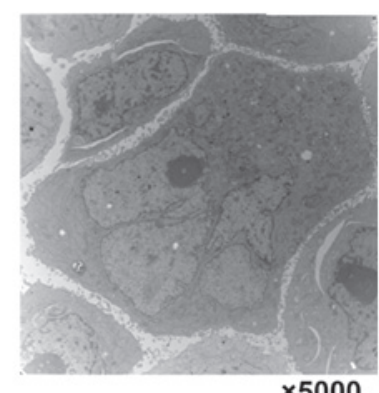

H

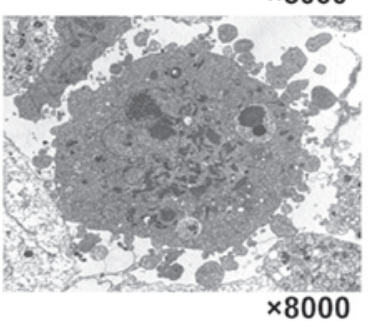

Figure 2. Typical characteristics of mitotic catastrophe and apoptotic morphological changes were observed in three types of tumor cell by transmission electron microscopy. In the control group, normal morphological characteristics of SGC-7901, MCF-7 and HepG2 tumor cells were observed, such as clear cellularity, integrated structure of the organelles and uniform distribution of chromatin, as demonstrated in (A) SGC-7901, (B) MCF-7 and (C) HepG2 cells. (D-F) Following treatment with $10 \mu \mathrm{mol} / 1$ chelidonine for $24 \mathrm{~h}$, nuclear envelopes randomly formed around chromatin, resulting in multinucleated SGC-7901, MCF-7 and HepG2 cells with multiple micronuclei of varying size. Following treatment with chelidonine for $48 \mathrm{~h}$, the number of multinucleated cells increased gradually. (G) Following treatment with $10 \mu \mathrm{mol} / 1$ chelidonine for $48 \mathrm{~h}$, the number of multinucleated SGC-7901 cells increased gradually. The multinuclear cells demonstrated the apoptotic morphology of reduced microvilli. (H) Following treatment with $10 \mu \mathrm{mol} / 1$ chelidonine for $72 \mathrm{~h}$, the multinuclear SGC-7901 cells exhibited chromatin condensation, nuclear fragmentation and the formation of apoptotic bodies.

Chelidonine regulates the protein expression levels of BubRI, Cdk1, cyclin B1 and caspase-3 in SGC-7901 cells. Following treatment with $10 \mu \mathrm{mol} / 1$ chelidonine for 48 and $72 \mathrm{~h}$, the expression levels of BubR1 in SGC-7901 cells decreased significantly (Fig. 5A and B). The expression level of cyclin B1 increased significantly at $0-24 \mathrm{~h}(\mathrm{P}<0.01)$, reached a peak at $24 \mathrm{~h}$, and then decreased in a time-dependent manner 


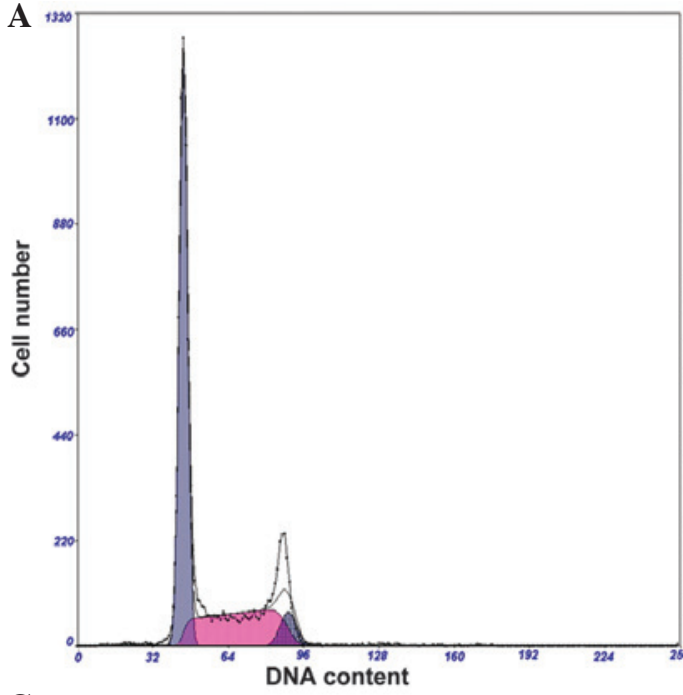

$\mathbf{C}$

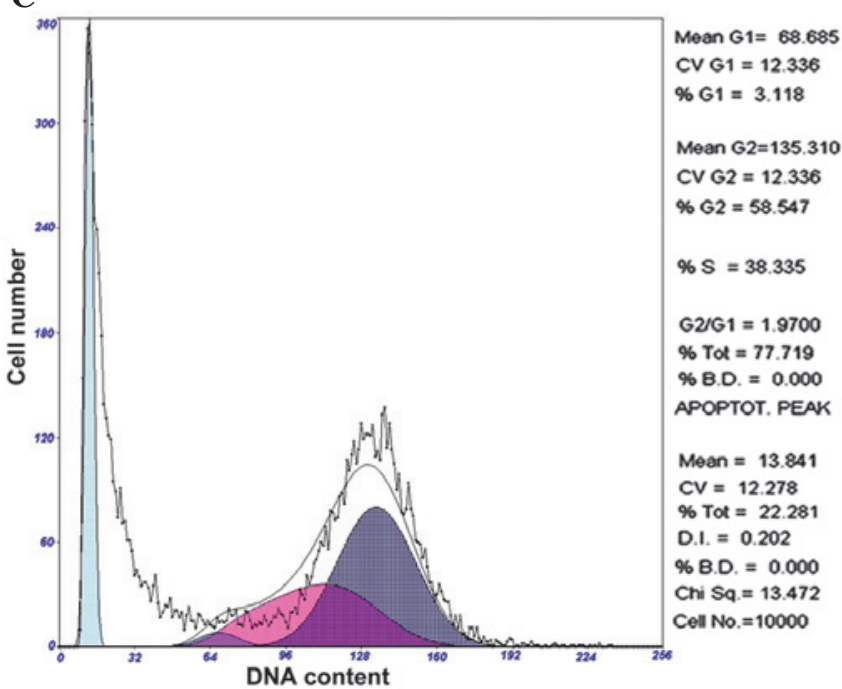

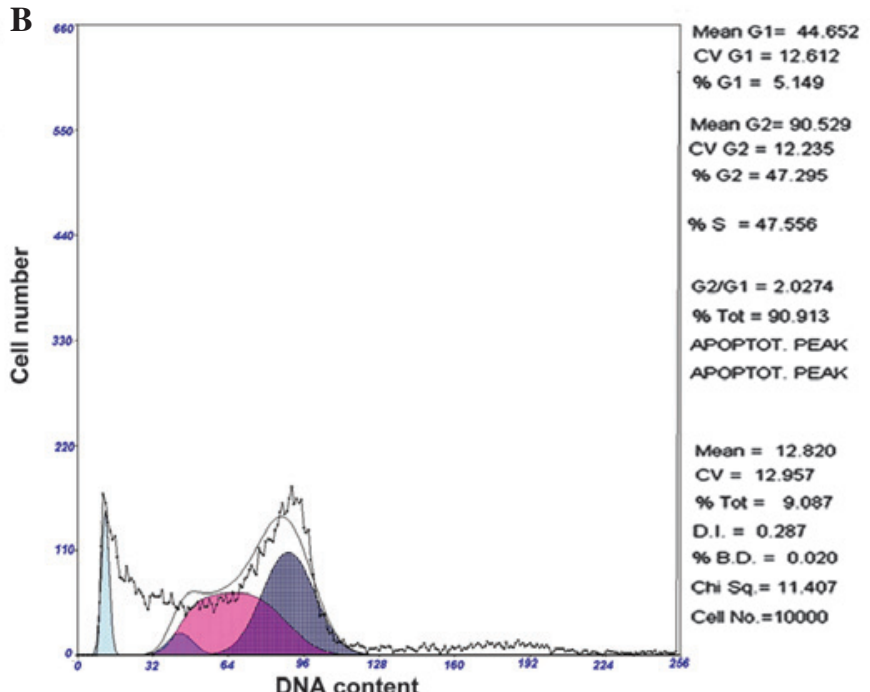

D

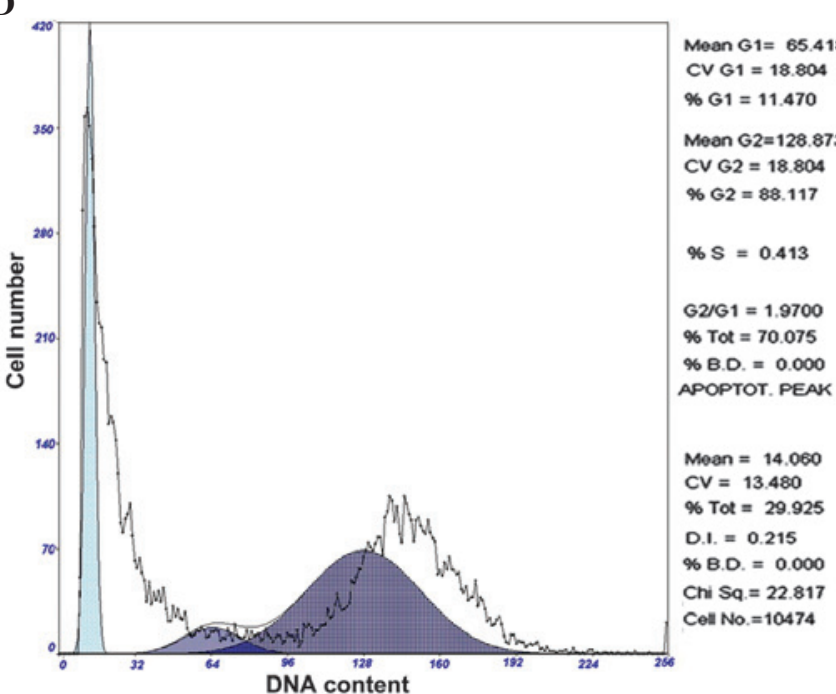

Figure 3. Effects of chelidonine on the $\mathrm{G}_{2} / \mathrm{M}$ phase arrest and SGC-7901 cell apoptosis were determined by flow cytometry with propidium iodide staining. (A) $\mathrm{The}_{\mathrm{G}} / \mathrm{M}$ phase cell ratio of the control group was $6.87 \%$. Following treatment with $10 \mu \mathrm{mol} / \mathrm{l}$ chelidonine for (B) $24 \mathrm{~h}$, the $\mathrm{G}_{2} / \mathrm{M}$ phase cell ratio was $47.30 \%$, which reached (C) $58.55 \%$ at $48 \mathrm{~h}$ and (D) $88.12 \%$ at $72 \mathrm{~h}$. The apoptosis rates were $9.09,22.28$ and $29.93 \%$ following treatment with chelidonine for 24,48 and $72 \mathrm{~h}$, respectively. The results suggest that chelidonine induces $\mathrm{G}_{2} / \mathrm{M}$ phase arrest and apoptosis in SGC-7901 cells. CV, coefficient of variation; $\% \mathrm{BD}$, background aggregates and debris; DI, DNA index.

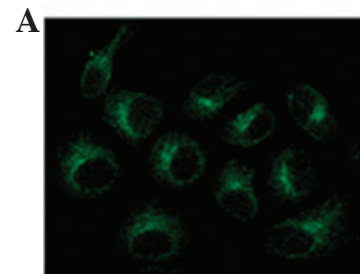

Control (RPMI-1640)

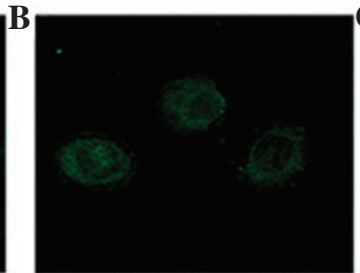

$\operatorname{VCR}(3 \mu \mathrm{mol} / \mathrm{l})$

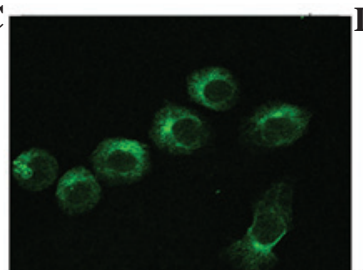

Chelidonine $(2.5 \mu \mathrm{mol} / \mathrm{l})$

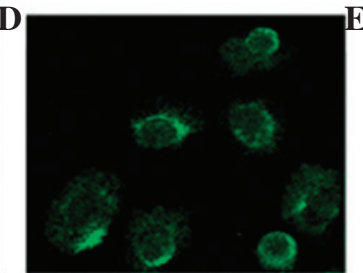

Chelidonine $(5 \mu \mathrm{mol} / \mathrm{l})$

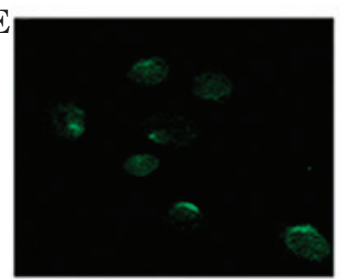

Chelidonine $(10 \mu \mathrm{mol} / \mathrm{l})$

Figure 4. Effects of chelidonine on tubulin in SGC-7901 cells were detected using laser scanning confocal microscopy following immunofluorescent labeling (magnification, $\mathrm{x} 400$ ). (A) The control microtubules were green fluorescent-labeled and they were distributed evenly in the cytoplasm surrounding the nucleus, and the single microtubules exhibited a clear outline and complete structure. (B) In the positive control group, the cells became round and the fluorescence intensity was weak. As a microtubule-targeting agent, VCR inhibited microtubule polymerization. (C) The microtubules of the SGC-7901 cells treated with $2.5 \mu \mathrm{mol} / 1$ chelidonine were not markedly affected. (D) The microtubules of SGC-7901 cells treated with $5 \mu \mathrm{mol} / 1$ chelidonine for $24 \mathrm{~h}$ demonstrated a discontinuous state and were reduced in number. (E) The microtubules of SGC-7901 cells treated with $10 \mu \mathrm{mol} / 1$ were not bundled, and demonstrated slight fluorescence, with diffuse, punctate and irregular distribution in the perinuclear region. VCR, vincristine.

(Fig. 5A and C). The expression levels of Cdk1 in SGC-7901 cells were maintained at $0-24 \mathrm{~h}$, but then decreased significantly at 24-72 h (Fig. 5A and $\mathrm{D} ; \mathrm{P}<0.01)$. The expression levels of caspase-3 increased in a time-dependent manner, and were significantly higher than those of the control group (Fig. $5 \mathrm{~A}$ and $\mathrm{E} ; \mathrm{P}<0.05$ or $\mathrm{P}<0.01$ ). 
A

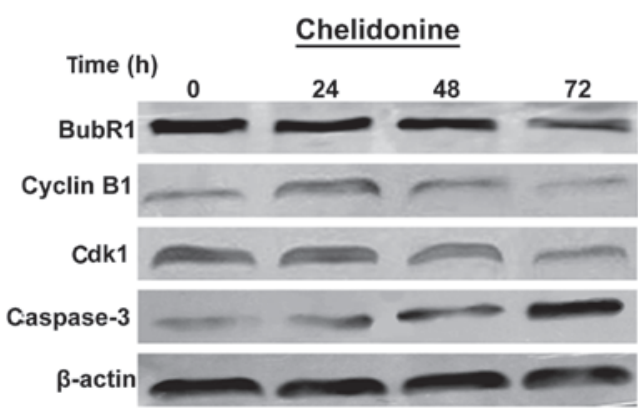

B

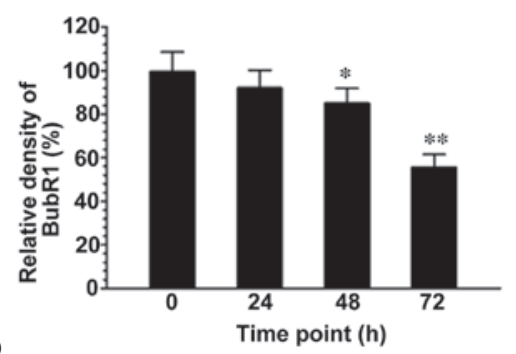

D

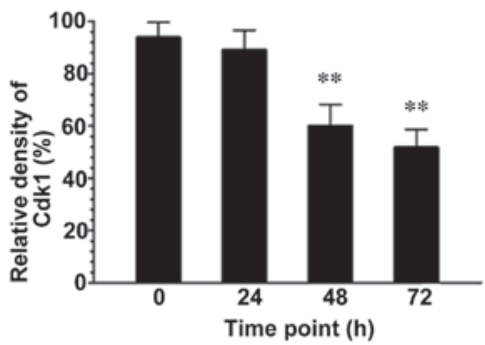

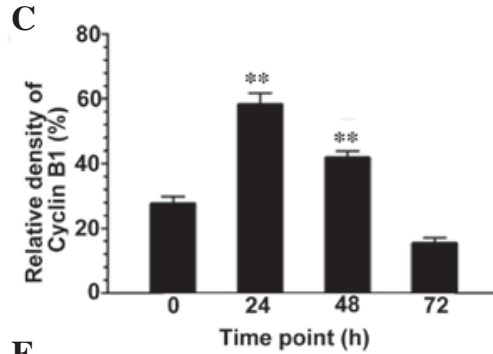

$\mathbf{E}$

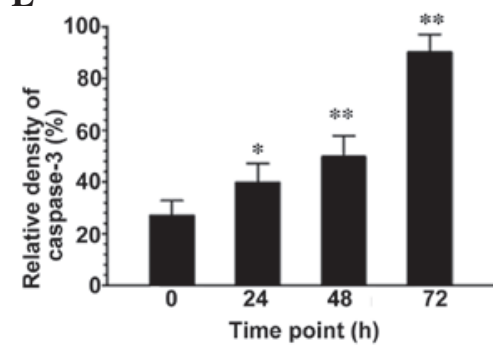

Figure 5. (A) Western blot analysis was performed to determine the expression levels of proteins associated with mitotic slippage and apoptotic-like death. Following treatment with $10 \mu \mathrm{mol} / 1$ chelidonine for 0, 24, 48 and $72 \mathrm{~h}$, the protein expression levels of (B) BubR1, (C) cyclin B1, (D) Cdk1 and (E) caspase-3 were analyzed. The data are presented as the mean \pm standard deviation of three independent experiments. ${ }^{*} \mathrm{P}<0.05,{ }^{* *} \mathrm{P}<0.01 \mathrm{vs}$. the control. BubR1, $\mathrm{BUB} 1$ mitotic checkpoint serine/threonine kinase B; Cdk1, cyclin-dependent kinase 1 .

\section{Discussion}

Mitotic catastrophe is a type of cell death resulting from abnormal mitosis with the formation of large cells that contain multiple nuclei in the mitotic phase (22). Mitotic catastrophe has been the subject of increasing research over recent years (23). Previous studies have demonstrated that ionizing radiation (24) and certain antitumor therapeutic agents, such as doxorubicin (25), paclitaxel (26) and VCR (27), may result in mitotic catastrophe in various solid tumors, which commonly contain nonfunctional p53 (28). Multiple factors determine whether cells undergo mitotic catastrophe, including the genetic background of the cell, the type of DNA damage, and the dosage and treatment duration of certain therapeutic agents. Although signaling pathways specific to mitotic catastrophe remain unclear, it is becoming increasingly important to continue investigating the mechanisms that result in the success of anticancer therapeutic strategies.

It has been observed that chelidonine induced cell apoptosis in Hela human cervical carcinoma, A375 malignant melanoma, CEM human T-leukemia and OCM-1 human uveal melanoma cells $(7,20,21,29)$. In addition, chelidonine induced $\mathrm{G}_{2} / \mathrm{M}$ phase arrest in MT-4 human acute T-lymphoblastic leukemia cells (30) and WHCO5 human esophageal carcinoma cells (31). As chelidonine possesses mitotic toxicity, it remains to be elucidated whether chelidonine induces mitotic catastrophe of tumor cells. In the present study, SGC-7901 human gastric carcinoma cells were selected to investigate the mitotic catastrophe-inducing effects and mechanisms of chelidonine.

Results from the current study demonstrated that chelidonine effectively inhibited the proliferation of SGC-7901 cells, and its $\mathrm{IC}_{50}$ was $23.13 \mu \mathrm{mol} / 1$. The predominant morphological characteristic of mitotic catastrophe is the formation of large cells that contain multiple nuclei, which is different from apoptosis $(23,32,33)$. The morphological changes were observed in
SGC-7901 cells. Following treatment with $10 \mu \mathrm{mol} / 1$ chelidonine for $24 \mathrm{~h}$, a number of giant cells with two or more nuclei were observed under a TEM. The number of giant and multinucleated cells markedly increased in a time- and dose-dependent manner, as observed under a TEM and optical microscope. In addition, according to the clinical application of $C$. majus, MCF-7 cells and HepG2 cells were selected to investigate the mitotic catastrophe-inducing effects of chelidonine. Following treatment with $10 \mu \mathrm{mol} / 1$ for $24 \mathrm{~h}$, the morphological characteristics of mitotic catastrophe were observed under a TEM. FCM indicated that administration of $10 \mu \mathrm{mol} / 1$ chelidonine induced $\mathrm{G}_{2} / \mathrm{M}$ phase arrest of SGC-7901 cells. However, the cells in the $G_{2}$ and $M$ phase could not be effectively distinguished by FCM as the FCM histogram of DNA content analysis was based on the DNA ploidy level in the cell nucleus. Thus, in the present study it could not be determined whether chelidonine induced $\mathrm{G}_{2}$ or $\mathrm{M}$ phase arrest in SGC-7901 cells. The expression of p-histone $\mathrm{H} 3\left(\mathrm{Ser}^{10}\right)$, which is a characteristic of $\mathrm{M}$ phase, reached a peak at mitotic metaphase and disappeared following the completion of mitosis. Furthermore, histone $\mathrm{H} 3$ phosphorylation is important in the DNA of the heteromorphic nuclear cells in the mitotic phase, which is an indicator of mitotic catastrophe $(34,35)$. Indirect immunofluorescence assay and an LSCM were used to detect the phosphorylation level of histone H3 $\left(\mathrm{Ser}^{10}\right)$ in SGC-7901 cells. Following treatment with chelidonine for $24 \mathrm{~h}$, the fluorescence intensity was enhanced with increasing chelidonine concentration. The result demonstrated that chelidonine treatment increased the phosphorylation of histone $\mathrm{H} 3\left(\mathrm{Ser}^{10}\right)$, indicating that chelidonine arrested the SGC-7901 cells in the $M$ phase rather than in $G_{2}$ phase. It was further investigated whether chelidonine also inhibited microtubule polymerization. An indirect immunofluorescence assay and LSCM were used to observe the effect of chelidonine on microtubule morphology in SGC-7901 cells. The results demonstrated that chelidonine inhibits tubulin polymerization, destroys microtubule structures and alters the cytoskeleton. 
As microtubules are important components of the cell spindle, chelidonine may affect the formation and function of the spindle; thus, inducing cell cycle arrest at $\mathrm{M}$ phase and resulting in abnormal mitosis, which finally leads to the formation of multipolar spindles and multinucleated cells.

Cell cycle checkpoint mechanisms are strict quality control systems that ensure the normal operation of the cell cycle. The spindle assembly checkpoint (SAC) is key in monitoring the proper alignment and separation of chromosomes, and ensures genome integrity of daughter cells. For cells entering into mitosis, whether the cells are able to exit the $\mathrm{M}$ phase, is controlled by the SAC (36). Under normal conditions, the anaphase-promoting complex (APC) is rapidly activated in mitotic cells in metaphase, destroying the adhesion of sister chromatids and inactivating the relevant Cdk complexes, thus the cells complete mitosis and undergo cytokinesis (37). The inhibiting mechanism for APC activity is the core function of the SAC. Any factors interfering with the correct combination of sister chromatids and spindles may directly or indirectly activate SAC signaling, and inhibit the activation of APC resulting in cell cycle arrest in the junction between the middle and late phase of mitosis (38). SAC is a signaling system composed of mutually coordinated proteins, in which BubR1 is an important receptor and implementer (39). BubR1 ensures proper separation of chromosomes continuing the process of cell mitosis via monitoring the status of the microtubule gap junction and tension in the centromeres (40). BubR1 is a direct inhibitor of APC (41). There is a dose-dependent effect between the expression level of BubR1 and the function of the SAC (42). The results in the present study demonstrate that following treatment with chelidonine for $72 \mathrm{~h}$, the protein expression level of BubR1 was significantly reduced $(\mathrm{P}<0.01)$. The low expression levels of BubR1 decreased the inhibition of APC, which resulted in compromised effects at the SAC $(43,44)$. In the absence of a thorough repair of damaged spindles, cells crossed the checkpoint and entered the $G_{1}$ phase of the next cell cycle, resulting in the formation of polyploid pseudo- $\mathrm{G}_{1}$ cells. These cells with a plurality of micronuclei remained in the $\mathrm{G}_{1}$ phase and were unable to survive (45).

It has been demonstrated that there is a correlation between cyclin B1-Cdk1 complexes [mitosis promoting factor (MPF)] activity and cell mitotic slippage (46-48). Therefore, the expression levels of cyclin B1 and Cdk1 proteins at different time-points were detected by western blotting. The results from the present study demonstrate that the protein expression levels of cyclin B1 increased significantly at 0-24 h, but then decreased in a time-dependent manner. The protein expression levels of Cdk1 remained stable at 0-24 h, but decreased significantly at 24-72 h. The progress of a cell from $\mathrm{G}_{2}$ to $\mathrm{M}$ phase is driven by the activation of the MPF. In early and mid-mitosis, the continuous activation of MPF is required. When the cells enter into anaphase, APC induces degradation of cyclin B1, and MPF activity is markedly reduced to ensure the normal completion of mitosis (49). Following treatment with chelidonine, microtubule polymerization was inhibited and the spindle function was affected in the SGC-7901 cells. The SAC was activated and SGC-7901 cells were arrested in the $\mathrm{M}$ phase. With the prolongation of mitotic arrest, the protein expression levels of BubR1 decreased, thus reducing the inhibition of APC and increasing degradation of cyclin B1 by APC (50). SGC-7901 cells underwent mitotic slippage and exited the mitotic phase, entering into a pseudo- $\mathrm{G}_{1}$ phase and, finally, the multinucleated cells underwent mitotic catastrophe.

Multinucleated cells cannot survive and, therefore, undergo cell death. Cell death by mitotic catastrophe is a complicated process and the cells may die due to apoptosis, senescence, necrosis or another death signaling pathway (22). It is hypothesized that apoptosis is one of the consequences of mitotic catastrophe (51). The results of the present study indicate that following treatment with chelidonine, the number of multinucleated cells increased gradually and demonstrated apoptotic morphology, including chromatin condensation, nuclear fragmentation and the formation of an apoptotic body. FCM, following staining of cells with PI, demonstrated that the apoptotic rate of SGC-7901 cells increased gradually and in a time-dependent manner with chelidonine treatment reaching $29.93 \%$ at $72 \mathrm{~h}$. To elucidate the underlying mechanisms of apoptosis upon treatment with chelidonine, the protein expression level of caspase-3 was detected. The results demonstrate that the protein expression of caspase- 3 also increased gradually and in a time-dependent manner with chelidonine treatment. The results indicate that apoptosis, induced by chelidonine in SGC-7901 cells undergoing mitotic catastrophe, may involve a caspase-3-dependent signaling pathway.

In conclusion, chelidonine induced $\mathrm{M}$ phase arrest and slippage of SGC-7901 human gastric carcinoma cells, which then underwent mitotic catastrophe. A number of the multinucleated cells underwent apoptosis-like cell death. Resistance of tumor cells to apoptosis is one of the leading causes of cancer treatment failure, chelidonine was demonstrated to induce mitotic catastrophe in tumor cells and, thus, avoid the resistance to apoptosis. Due to its unique mechanism and novel target, chelidonine is hypothesized to be a promising therapeutic agent in the treatment of various cancers, including gastric cancer, hepatocellular carcinoma and breast cancer. The further elucidation of the underlying anti-cancer molecular mechanism of chelidonine provides novel scientific evidence for the research and application of chelidonine-associated anticancer therapeutic agents.

\section{Acknowledgements}

The present study was supported by the National Natural Science Foundation of China (grant no. 81102858); the China Postdoctoral Science Foundation (grant no. 2013M531060); the Research Fund for the Doctoral Program of Higher Education (grant no. 20102332120003); the Key Project of Chinese Ministry of Education (grant no. 210059); the Natural Science Foundation of Heilongjiang Province (grant no. D200817); the Heilongjiang Postdoctoral Foundation (grant no. LBH-Z10103); and the Heilongjiang Provincial Key Teachers Project (grant no. 1154G35).

\section{References}

1. De Vita F, Di Martino N, Fabozzi A, Laterza MM, Ventriglia J, Savastano B, Petrillo A, Gambardella V, Sforza V, Marano L, et al: Clinical management of advanced gastric cancer: The role of new molecular drugs. World J Gastroenterol 20: 14537-14558, 2014. 
2. Cives M, Ciavarella S, Rizzo FM, De Matteo M, Dammacco F and Silvestris F: Bendamustine overcomes resistance to melphalan in myeloma cell lines by inducing cell death through mitotic catastrophe. Cell Signal 25: 1108-1117, 2013

3. Zhao GP, Dai S, Chen RS, Wen HM, Yin L, Shi LW, Shi XD, Liu WL, Liu XH, Li Y, et al: Dictionary Chinese materia medica. In: Dictionary Chinese Materia Medica. Yu HA and Liu SF (eds) Vol 1. 2nd edition. Shanghai Science and Technology Press, Shanghai, p1000, 2006

4. Chinese Pharmacopoeia Commission: Pharmacopoeia of the People's Republic of China. In: Pharmacopoeia of the People's Republic of China. Zhao YY (ed). Vol 1. 10th edition. Medicine Science and Technology Press of China, Beijing, p109, 2015.

5. He ZM, Tong JM and Gong FC: Study on the analgesic effect of Chelidonium majus L. Chin Tradit Herb Drugs 34: 837-838, 2003

6. Colombo ML and Bosisio E: Pharmacological activities of Chelidonium majus L. (Papaveraceae). Pharmacol Res 33: $127-134,1996$

7. Noureini SK and Wink M: Transcriptional down regulation of hTERT and senescence induction in HepG2 cells by chelidonine. World J Gastroenterol 15: 3603-3610, 2009.

8. Paul A, Bishayee K, Ghosh S, Mukherjee A, Sikdar S, Chakraborty D, Boujedaini $\mathrm{N}$ and Khuda-Bukhsh AR: Chelidonine isolated from ethanolic extract of Chelidonium majus promotes apoptosis in HeLa cells through p38-p53 and PI3K/AKT signalling pathways. J Chin Integ Med 10: 1025-1038, 2012.

9. Paul A, Das S, Das J, Samadder A and Khuda-Bukhsh AR: Cytotoxicity and apoptotic signalling cascade induced by chelidonine-loaded PLGA nanoparticles in HepG2 cells in vitro and bioavailability of nano-chelidonine in mice in vivo. Toxicol Lett 222: 10-22, 2013

10. Park JE, Cuong TD, Hung TM, Lee I, Na M, Kim JC, Ryoo S, Lee JH, Choi JS, Woo MH and Min BS: Alkaloids from Chelidonium majus and their inhibitory effects on LPS-induced NO production in RAW264.7 cells. Bioorg Med Chem Lett 21: 6960-6963, 2011.

11. Heinle H, Hagelauer D, Pascht U, Kelber O and Weiser D Intestinal spasmolytic effects of STW 5 (Iberogast) and its components. Phytomedicine 13 (Suppl 5): 75-79, 2006.

12. Iagodina OV, Niko/skaia EB and Faddeeva MD: Inhibition of liver mitochondrial monoamine oxidase activity by alkaloids isolated from Chelidonium and Macleaya and by their derivative drugs. Tsitologiia 45: 1032-1037, 2003 (In Russian).

13. Paul A, Das J, Das S, Samadder A and Khuda-Bukhsh AR: Poly (lactide-co-glycolide) nano-encapsulation of chelidonine, an active bioingredient of greater celandine (Chelidonium majus), enhances its ameliorative potential against cadmium induced oxidative stress and hepatic injury in mice. Environ Toxicol Pharmacol 36: 937-947, 2013

14. Koriem KM, Arbid MS and Asaad GF: Chelidonium majus leaves methanol extract and its chelidonine alkaloid ingredient reduce cadmium-induced nephrotoxicity in rats. J Nat Med 67: 159-167, 2013.

15. Staniszewski A, Slesak B, Kołodziej J, Harłozińska-Szmyrka A and Nowicky JW: Lymphocyte subsets in patients with lung cancer treated with thiophosphoric acid alkaloid derivatives from Chelidonium majus L. (Ukrain). Drugs Exp Clin Res 18 (Suppl): 63-67, 1992.

16. Kadan P, Korsh OB and Melnyk A: Ukrain therapy of recurrent breast cancer with lung metastases (case report). Drugs Exp Clin Res 22: 243-245, 1996.

17. Uglyanitsa KN, Nechiporenko NA, Nefyodov LI, Doroshenko YM, Brzosko W and Nowicky W: Results of Ukrain monotherapy of prostate cancer. Drugs Exp Clin Res 26: 191-193, 2000.

18. Zemskov V, Prokopchuk O, Susak Y, Zemskov S, Tkachenko O, Hodysh Y and Nowicky W: Efficacy of ukrain in the treatment of pancreatic cancer. Langenbecks Arch Surg 387: 84-89, 2002.

19. El-Readi MZ, Eid S, Ashour ML, Tahrani A and Wink M: Modulation of multidrug resistance in cancer cells by chelidonine and Chelidonium majus alkaloids. Phytomedicine 20: 282-294, 2013

20. Hammerová J, Uldrijan S, Táborská E and Slaninová I: Benzo[c] phenanthridine alkaloids exhibit strong anti-proliferative activity in malignant melanoma cells regardless of their p53 status. J Dermatol Sci 62: 22-35, 2011.

21. Kaminskyy V, Kulachkovskyy O and Stoika R: A decisive role of mitochondria in defining rate and intensity of apoptosis induction by different alkaloids. Toxicol Lett 177: 168-181, 2008 .
22. Vitale I, Galluzzi L, Castedo M and Kroemer G: Mitotic catastrophe: A mechanism for avoiding genomic instability. Nat Rev Mol Cell Biol 12: 385-392, 2011.

23. Caruso R, Fedele F, Lucianò R, Branca G, Parisi C, Paparo $\mathrm{D}$ and Parisi A: Mitotic catastrophe in malignant epithelial tumors: The pathologis'/s viewpoint. Ultrastruct Pathol 35: 66-71, 2011

24. Lindgren T, Stigbrand T, Johansson L, Riklund K and Eriksson D: Alterations in gene expression during radiation-induced mitotic catastrophe in HeLa Hep2 cells. Anticancer Res 34: 3875-3880, 2014.

25. Grzanka D, Marszałek A, Izdebska M, Gackowska L, Andrzej Szczepanski M and Grzanka A: Actin cytoskeleton reorganization correlates with cofilin nuclear expression and ultrastructural changes in cho aa8 cell line after apoptosis and mitotic catastrophe induction by doxorubicin. Ultrastruct Pathol 35: 130-138, 2011.

26. Wang X, Wu E, Wu J, Wang TL, Hsieh HP and Liu X: An antimitotic and antivascular agent BPR0L075 overcomes multidrug resistance and induces mitotic catastrophe in paclitaxel-resistant ovarian cancer cells. PLoS One 8: e65686, 2013.

27. Magalska A, Sliwinska M, Szczepanowska J, Salvioli S, Franceschi C and Sikora E: Resistance to apoptosis of HCW-2 cells can be overcome by curcumin- or vincristine-induced mitotic catastrophe. Int J Cancer 119: 1811-1818, 2006.

28. Mansilla S, Bataller M and Portugal J: Mitotic catastrophe as a consequence of chemotherapy. Anticancer Agents Med Chem 6: 589-602, 2006

29. Kemény-Beke A, Aradi J, Damjanovich J, Beck Z, Facskó A, Berta A and Bodnár A: Apoptotic response of uveal melanoma cells upon treatment with chelidonine, sanguinarine and chelerythrine. Cancer Lett 237: 67-75, 2006.

30. Philchenkov A, Kaminskyy V, Zavelevich M and Stoika R: Apoptogenic activity of two benzophenanthridine alkaloids from Chelidonium majus L. does not correlate with their DNA damaging effects. Toxicol In Vitro 22: 287-295, 2008.

31. Panzer A, Joubert AM, Bianchi PC, Hamel E and Seegers JC: The effects of chelidonine on tubulin polymerisation, cell cycle progression and selected signal transmission pathways. Eur J Cell Biol 80: 111-118, 2001.

32. Ji YB, Qu ZY and Zou X: Juglone-induced apoptosis in human gastric cancer SGC-7901 cells via the mitochondrial pathway. Exp Toxicol Pathol 63: 69-78, 2011.

33. Kundu S, Kim TH, Yoon JH, Shin HS, Lee J, Jung JH and Kim HS: Viriditoxin regulates apoptosis and autophagy via mitotic catastrophe and microtubule formation in human prostate cancer cells. Int J Oncol 45: 2331-2340, 2014

34. Roy RV, Suman S, Das TP, Luevano JE and Damodaran C: Withaferin A, a steroidal lactone from Withania somnifera, induces mitotic catastrophe and growth arrest in prostate cancer cells. J Nat Prod 76: 1909-1915, 2013.

35. de-Sá-Júnior PL, Pasqualoto KF, Ferreira AK, Tavares MT, Damião MC, de Azevedo RA, Câmara DA, Pereira A, de Souza DM and Parise Filho R: RPF101, a new capsaicin-like analogue, disrupts the microtubule network accompanied by arrest in the $\mathrm{G} 2 / \mathrm{M}$ phase, inducing apoptosis and mitotic catastrophe in the MCF-7 breast cancer cells. Toxicol Appl Pharmacol 266: 385-398, 2013

36. Suematsu T, Li Y, Kojima H, Nakajima K, Oshimura M and Inoue T: Deacetylation of the mitotic checkpoint protein BubR1 at lysine 250 by SIRT2 and subsequent effects on BubR1 degradation during the prometaphase/anaphase transition. Biochem Biophys Res Commun 453: 588-594, 2014.

37. Yu H: Regulation of APC-Cdc20 by the spindle checkpoint. Curr Opin Cell Biol 14: 706-714, 2002.

38. Lane SI and Jones KT: Non-canonical function of spindle assembly checkpoint proteins after APC activation reduces aneuploidy in mouse oocytes. Nat Commun 5: 3444, 2014.

39. Kapanidou M, Lee S and Bolanos-Garcia VM: BubR1 kinase: Protection against aneuploidy and premature aging. Trends $\mathrm{Mol}$ Med 21: 364-372, 2015.

40. Bolanos-Garcia VM,Nilsson J and Blundell TL: The architecture of the BubR1 tetratricopeptide tandem repeat defines a protein motif underlying mitotic checkpoint-kinetochore communication. Bioarchitecture 2: 23-27, 2012.

41. Ibrahim B: Systems biology modeling of five pathways for regulation and potent inhibition of the anaphase-promoting complex (APC/C): Pivotal roles for MCC and BubR1. OMICS 19: 294-305, 2015. 
42. Lentini L, Piscitello D, Veneziano L and Di Leonardo A: Simultaneous reduction of MAD2 and BUBR1 expression induces mitotic spindle alterations associated with p53 dependent cell cycle arrest and death. Cell Biol Int 38: 933-941, 2014.

43. Patel D and McCance DJ: Compromised spindle assembly checkpoint due to altered expression of Ubch10 and Cdc20 in human papillomavirus type 16 E6- and E7-expressing keratinocytes. J Virol 84: 10956-10964, 2010.

44. Lara-Gonzalez P, Scott MI, Diez M, Sen O and Taylor SS: BubR1 blocks substrate recruitment to the APC/C in a KEN-box-dependent manner. J Cell Sci 124: 4332-4345, 2011.

45. Brito DA and Rieder CL: Mitotic checkpoint slippage in humans occurs via cyclin B destruction in the presence of an active checkpoint. Curr Biol 16: 1194-1200, 2006.

46. Galán-Malo P, Vela L, Gonzalo O, Calvo-Sanjuán R, Gracia-Fleta L, Naval J and Marzo I: Cell fate after mitotic arrest in different tumor cells is determined by the balance between slippage and apoptotic threshold. Toxicol Appl Pharmacol 258: $384-393,2012$
47. Qi M, Yao G, Fan S, Cheng W, Tashiro S, Onodera S and Ikejima T: Pseudolaric acid B induces mitotic catastrophe followed by apoptotic cell death in murine fibrosarcoma L929 cells. Eur J Pharmacol 683: 16-26, 2012.

48. Liu WT, Chen C, Lu IC, Kuo SC, Lee KH, Chen TL, Song TS, Lu YL, Gean PW and Hour MJ: MJ-66 induces malignant glioma cells G2/M phase arrest and mitotic catastrophe through regulation of cyclin B1/Cdk1 complex. Neuropharmacology 86: 219-227, 2014.

49. Jin SQ and Zhan QM: Cell cycle checkpoint and tumour. In: Molecular Oncology. Liu S (ed). People's Medical Publishing House, Beijing, p364, 2005.

50. Giovinazzi S, Bellapu D, Morozov VM and Ishov AM: Targeting mitotic exit with hyperthermia or APC/C inhibition to increase paclitaxel efficacy. Cell Cycle 12: 2598-2607, 2013.

51. Castedo M, Perfettini JL, Roumier T, Valent A, Raslova H, Yakushijin K, Horne D, Feunteun J, Lenoir G, Medema R, et al. Mitotic catastrophe constitutes a special case of apoptosis whose suppression entails aneuploidy. Oncogene 23: 4362-4370, 2004. 